\title{
A new approach for concurrently improving performance of South Korean food waste valorization and renewable energy recovery via dry anaerobic digestion under mesophilic and thermophilic conditions
}

\author{
Dinh Duc Nguyen ${ }^{\mathrm{a}, \mathrm{b}}$, , Jeong Seong Yeop ${ }^{\mathrm{b}}$, Jaehoon Choi ${ }^{\mathrm{b}}$, Sungsu Kim ${ }^{\mathrm{b}}$, Soon Woong \\ Chang $^{\mathrm{b}, *}$, ,Byong-Hun Jeon ${ }^{\mathrm{c}}$, Wenshan Guo ${ }^{\mathrm{d}}$, Huu Hao Ngo ${ }^{\mathrm{d}, *}$ \\ ${ }^{a}$ Department for Management of Science and Technology Development \& Faculty of Environment and \\ Labour Safety, Ton Duc Thang University, Ho Chi Minh City, Viet Nam \\ ${ }^{b}$ Department of Environmental Energy \& Engineering, Kyonggi University, Republic of Korea \\ ${ }^{c}$ Department of Earth Resources and Environmental Engineering, Hanyang University, Seoul 04763, \\ South Korea \\ ${ }^{d}$ Centre for Technology in Water and Wastewater, School of Civil and Environmental Engineering, \\ University of Technology Sydney (UTS), Broadway, NSW 2007, Australia \\ * Corresponding authors. E-mail addresses: nguyendinhduc@tdt.edu.vn (D.D. Nguyen), \\ swchang@kyonggi.ac.kr (S.W. Chang), huuhao.ngo@uts.edu.au (H.H.Ngo).
}

\begin{abstract}
Dry semicontinuous anaerobic digestion (AD) of South Korean food waste (FW) under four solid loading rates (SLRs) $\left(2.30-9.21 \mathrm{~kg}\right.$ total solids (TS) $/ \mathrm{m}^{3}$ day) and at a fixed TS content was compared between two digesters, one each under mesophilic and thermophilic conditions. Biogas production and organic matter reduction in both digesters followed similar trends, increasing with rising SLR. Inhibitor (intermediate products of the anaerobic fermentation process) effects on the digesters' performance were not observed under the studied conditions. In all cases tested, the digesters' best performance was achieved at the SLR of $9.21 \mathrm{~kg} \mathrm{TS} / \mathrm{m}^{3}$ day, with $74.02 \%$ and $80.98 \%$ reduction of volatile solids (VS), 0.87 and $0.90 \mathrm{~m}^{3}$ biogas $/ \mathrm{kg} \mathrm{VS}_{\text {removed, }}$ and $0.65(65 \%$ $\left.\mathrm{CH}_{4}\right)$ and $0.73\left(60.02 \% \mathrm{CH}_{4}\right) \mathrm{m}^{3}$ biogas $/ \mathrm{kg} \mathrm{VS}_{\text {fed }}$, under mesophilic and thermophilic conditions, respectively. Thermophilic dry AD is recommended for FW treatment in South Korea because it is more efficient and has higher energy recovery potential when compared to mesophilic dry AD.
\end{abstract}

Keywords: Dry anaerobic digestion; Solids loading rate; Mesophilic condition; Thermophilic condition; Food waste; Renewable energy recovery

\section{Introduction}

Food waste (FW) has long been identified as a threat to human health and the environment (Cho et al., 2013; Hamilton et al., 2015; Salemdeeb et al., 2017 ; Zhang et al., 2011) because it can generate considerable quantities of pathogens, pollutants (greenhouse gases and odorants), and contaminants (organic matter and nutrients) if it is not managed and handled properly. Large quantities of FW are generated every day worldwide through human activities - approximately one-third of food production for human consumption goes to waste (Thyberg and Tonjes, 2016; Uçkun Kiran et al., 2014 ; Yu et al., 2016). This is equivalent to 1.3 billion tons of food wasted annually (Fisgativa et al., 2016), which is a major contribution to municipal solid waste (Pham et al., 2015; Zhang et al., 2011), possibly up to 45\% (Cho et al., 2013). In South Korea, from 2003 to 2014 , the amount of FW varied from 4.2 to 5.5 million tons per year (22.46-29.08\%, respectively, of municipal solid waste) (Korea Ministry of Environment, 2016). On the positive 
side, FW does constitute a significant year-round potential source of quality alternative biomass material, as it contains high organic content (in dry matter: 35.5-69\% sugar and 3.9-21.9\% protein (Uçkun Kiran et al., 2014) and moisture (75-85\%) (Wang et al., 2014a). It is also suitable for biodegradation and renewable energy recovery (Cho et al., 2013; Hamilton et al., 2015; Kim and Oh, 2011; Wang et al., 2014b).

Therefore, utilization of FW can significantly reduce both operating costs of FW treatment plants and damage to the environment and increase economic benefits derived from the production and use of sustainable energy (e.g., subsidies on renewable energy, carbon taxation, carbon credits, etc.). During the last decade, to achieve sustainable waste management strategies, South Korea's government has enforced strict policies that cut production and/or increase recycling of $\mathrm{FW}$ (Environment, 2014), such as legislation, regulations, and standards as well as increased disposal fees based on volume (2010) (Cho et al., 2013; Lee and Paik, 2011; Park and Lah, 2015). However, despite urbanization, rapidly rising living standards, and a population explosion from 2010 to 2014 that increased the population by $2.01 \%$ (to 50.424 million people, 2014), it seems the average annual total FW yield did not differ significantly, with 4.99 million tons FW/year (average $0.277 \mathrm{~kg} \mathrm{FW} /$ person-day) in 2010 and 5 million tons FW/year (average $0.272 \mathrm{~kg}$ FW/person·day) in 2014 (Korea Ministry of Environment, 2016). South Korea has the world's largest average ratio of FW generation per capita (Lim et al., 2008).

In South Korea, the most common management solutions for FW are feeding it to animals or using it as fertilizer to improve the structure and increase the porosity of the soil. However, these approaches have become less attractive, due to newly issued regulations as well as limitations in the quality of products and in the control of potentially hazardous pathogens and antibioticresistant genes (Kim and Oh, 2011; Wang et al., 2014a; Zhang et al., 2016 ; Zhang et al., 2011). Meanwhile, landfilling or burning of FW has been banned since 2005 (Cho et al., 2013; Lim et al., 2008). Therefore, with the aim of creating a sustainable economy and society, the government's objectives are to develop efficient, economical, mitigative technologies and alternative methods for simultaneous FW valorization and enhanced renewable energy generation. This plan is for both now and in the future, to offer solutions for improving the current treatment system (Cho et al., 2013; Lim et al., 2008). For the purpose of organic waste management and renewable energy recovery, anaerobic digestion (AD) technology has been rated as an effective method and widely applied in practice (Bohutskyi et al., 2015; Gonzalez-Fernandez et al., 2015; Zhang et al., 2011). Currently, depending on the content of total solids (TS) in the raw biomass, AD technology is basically divided into three categories: wet ( $\leq 10 \% \mathrm{TS})$, semidry (10-20\% TS), and dry ( $\geq 20 \% \mathrm{TS})$ processes (Abbassi-Guendouz et al., 2012). Wet AD has been studied widely in recent years for the treatment of FW or mixtures of FW with other types of waste, such as garden waste, livestock manure (cows, horses, pigs and chickens), sewage sludge, etc. (Fitamo et al., 2016; Wang et al., 2014b; Zhang et al., 2016), with the results indicating that volatile solids (VS) reduction and methane $\left(\mathrm{CH}_{4}\right)$ production rate could reach $75 \%$ and $0.51 \mathrm{~L} \mathrm{CH}_{4} / \mathrm{g} \mathrm{VS}$, respectively. However, many problems are associated with this type of digester; for example, they require large volumes and are sensitivities, and failure may even occur if there are changes during system operation. These changes include variations in organic loading rate, ammonia nitrogen $\left(\mathrm{NH}_{4}-\mathrm{N}\right)$ concentration, pH, volatile fatty acids (VFAs), heavy metals, alkalinity, etc. (Fisgativa et al., 2016 ; Forster-Carneiro et al., 2008). 
In recent years, several studies on dry AD under mesophilic $\left(20-45^{\circ} \mathrm{C}\right)$ or thermophilic $(41-$ $70{ }^{\circ} \mathrm{C}$ ) conditions have been conducted on the organic fraction of municipal solid waste (Benbelkacem et al., 2015; Fernández et al., 2008), lignocellulosic substrates (Brown et al., 2012), and FW (Cho et al., 2013). All of these have generally demonstrated the dry AD technology's economical and engineering feasibility and report several advantages and benefits, such as high organic loading rate, high biogas volumetric efficiency, low water content, and small digestate. However, dry AD does have several limitations that need to be overcome, for instance, long startup and degradation times and sensitivity to inhibitors, which are intermediate products of the anaerobic fermentation process (Banks et al., 2011; Forster-Carneiro et al., 2008 ; Huang et al., 2016).

Although dry $\mathrm{AD}$ has received special attention from the global scientific community recently, there seems to be no consistency among the early studies (Banks et al., 2011 ; Fernández et al., 2008), due to their heterogeneity of experimental conditions, e.g., variations in the environmental conditions, physicochemical characteristics of the substrates, seasons, regions, cultures, policies, etc. (Cho et al., 2013; Thyberg and Tonjes, 2016; Uçkun Kiran et al., 2014 ; Zhang et al., 2007). Furthermore, no studies to date have calculated the recoverable FW energy potential of dry AD. Generally, available information in the literature concerning dry AD under thermophilic and mesophilic conditions in the field of valorization and conversion of FW for renewable energy recovery is very limited; thus, the exact mechanisms of such are not fully understood. Additionally, FW characteristics are the main factors directly affecting the anaerobic decomposition process (Uçkun Kiran et al., 2014; Zhang et al., 2007). For this reason, research on dry AD for South Korean FW is urgently needed. The results of the present study should provide a more effective solution for South Korea's Waste-to-Energy mandates as well as valuable information to the global scientific community.

Therefore, the purposes of this research were to: (1) examine the performance of thermophilic and mesophilic dry AD for FW valorization under solids loading rates (SLR) that were increased stepwise from 2.3 to $9.21 \mathrm{~kg} \mathrm{TS} / \mathrm{m}^{3}$ day at a fixed TS content of $22 \%$; (2) evaluate the biogas production and organic matter reduction during each process phase; (3) explain the relationship between SLR and renewable energy production; (4) evaluate the potential for converting South Korea's FW into renewable energy via dry AD under different conditions; and (5) estimate electricity generation from the biogas produced using these treatment technologies for $\mathrm{FW}$. In addition, the influence of the intermediate products of the $\mathrm{AD}$ process on the operational performance of the digesters was investigated.

\section{Materials and methods}

\subsection{Characteristics of the $F W$ and inoculums}

The corresponding FW and inoculum used in this study were obtained from the student cafeterias located in Kyonggi University, South Korea and a large-scale mesophilic dry AD plant of FW in "P" city, South Korea, respectively. Immediately after collection, the raw FW was crushed into particles smaller than $2 \mathrm{~mm}$ in size by a crusher and stored in a refrigerator $\left(0-4{ }^{\circ} \mathrm{C}\right)$ prior to the dry AD experiments. 
The main characteristics of TS, VS, VS/TS ratio, total chemical oxygen demand (TCOD), total nitrogen $(\mathrm{TN}), \mathrm{NH}_{4}-\mathrm{N}$, and $\mathrm{C} / \mathrm{N}$ ratio of the $\mathrm{FW}$ and inoculum are outlined in Table 1 and described in our previous work (Nguyen et al., 2017 ; Nguyen et al., 2016).

Table 1

Characteristics of the food waste and inoculum used for the dry AD experiments.

\begin{tabular}{llll}
\hline Parameters & Unit & Food waste & Inoculum \\
\hline $\mathrm{pH}$ & - & 4.91 & 7.62 \\
Total solids (TS) & $\%$ & $23.02(2.22)$ & 20.02 \\
Volatile solids (VS) & $\%$ & $20.55(0.84)$ & 12.59 \\
VS/TS & $\%$ & $91.53(2.34)$ & 69.54 \\
Total chemical oxygen demand & $\mathrm{mg} /$ & 220,000 & 72,000 \\
$\quad(\mathrm{TCOD})$ & $\mathrm{kg}$ & $(5739)$ & \\
Total nitrogen (TN) & $\mathrm{mg} /$ & $3650(162)$ & 4200 \\
& $\mathrm{~kg}$ & & \\
Ammonia nitrogen $\left(\mathrm{NH}_{4}-\mathrm{N}\right)$ & $\mathrm{mg} /$ & $900(187)$ & 1800 \\
& $\mathrm{~kg}$ & & \\
C/N ratio & - & 14.58 & - \\
\hline
\end{tabular}

The standard deviation are in parentheses.

\subsection{Experimental setup and operational conditions}

Two independent, dry, semi-continuous anaerobic digesters were operated under mesophilic $\left(38^{\circ} \mathrm{C}\right)$ and thermophilic $\left(55^{\circ} \mathrm{C}\right)$ conditions (Fig. 1). The total and effective volumes of each dry anaerobic digester were $20 \mathrm{~L}$ and $10 \mathrm{~L}$, respectively. The digesters were mounted with a hot water jacket system to control the operating temperature, which was set in advance depending on each digester's requirements; an agitator to mix the contents completely (anaerobic microbes, substrates, etc.) at a constant $30 \mathrm{rpm}$; and temperature probes for continuous online measurement. The circulating pump was integrated into a hot water jacket system to ensure uniform hot water in the system and eliminate dead zones. All the electrical equipment (pumps, sensors, and agitator) used in each AD system was able to operate and record in two modes: automatic and manual (Nguyen et al., 2017).
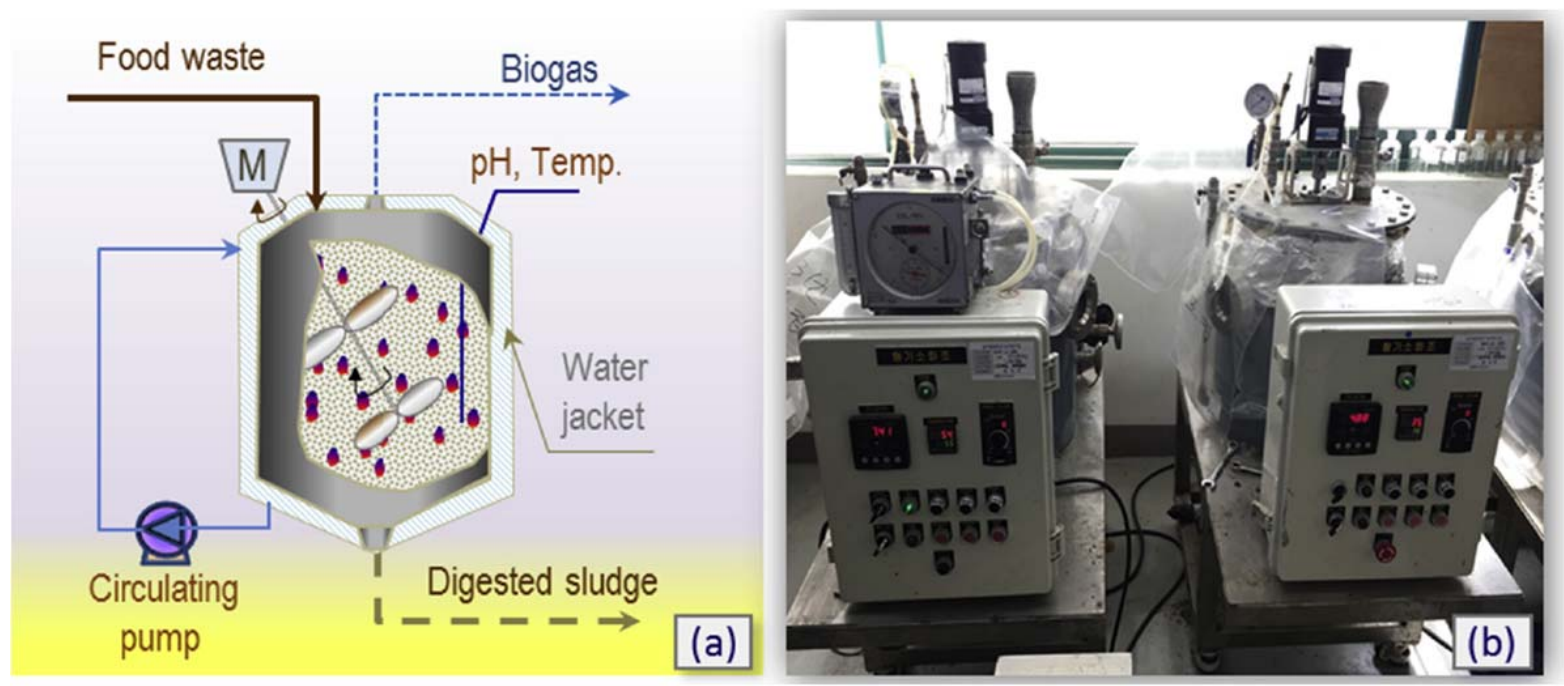

Fig. 1. Schematic diagram (a) and photo (b) of the dry anaerobic digester used in this study 
Initially, $10 \mathrm{~L}$ of inoculum was added into each dry anaerobic digester for quick startup with the anaerobic microorganisms. The digesters were operated under solids loading rates (SLRs) that increased stepwise from 2.3 to $9.21 \mathrm{~kg} \mathrm{TS} / \mathrm{m}^{3}$ day at a fixed TS content of $22 \%$, corresponding to hydraulic retention times (HRTs) from 100 days to 25 days, respectively (Nguyen et al., 2017). Operational details are summarized in Table 2.

Table 2. Operational strategies and conditions of the dry AD.

\begin{tabular}{llllll}
\hline Phase & $\begin{array}{l}\text { Retention time } \\
\text { days }\end{array}$ & $\begin{array}{l}\text { Operation time } \\
\text { days }\end{array}$ & $\begin{array}{l}\text { Organic loading rate } \\
\mathbf{k g ~ V S} / \mathbf{m}^{\mathbf{3}} \text { digester day }\end{array}$ & $\begin{array}{l}\text { Solids loading rate } \\
\mathbf{k g ~ T S} / \mathbf{m}^{\mathbf{3}} \text { digester day }\end{array}$ & $\begin{array}{c}\text { Number of samples } \\
{ }^{\mathbf{a}}\end{array}$ \\
\hline P1 & 100 & 9 & 2.16 & 2.3 & 8 \\
P2 & 60 & 13 & 3.58 & 3.82 & 13 \\
P3 & 30 & 20 & 7.18 & 7.67 & 20 \\
P4 & 25 & 59 & 8.62 & 9.21 & 59 \\
\hline
\end{tabular}

${ }^{\mathrm{a}}$ The samples were taken when the digester had stabilized.

To investigate the effect of SLR on the digesters' performance during each phase, different quantities of FW were added to the digesters once a day throughout the study period, and the SLRs were maintained at $2.3 \pm 0.22 \mathrm{~kg} \mathrm{TS} / \mathrm{m}^{3}$ day for $\mathrm{P} 1,3.82 \pm 0.37 \mathrm{~kg} \mathrm{TS} / \mathrm{m}^{3}$ day for $\mathrm{P} 2$, $7.67 \pm 0.74 \mathrm{~kg} \mathrm{TS} / \mathrm{m}^{3}$ day for P3, and $9.21 \pm 0.89 \mathrm{~kg} \mathrm{TS} / \mathrm{m}^{3}$ day for P4, with HRTs of 100, 60, 30, and 25 days, respectively (Table 2). To acclimatize the population of microorganisms in the digester, during $\mathrm{P} 1$ and $\mathrm{P} 2$, both the thermophilic dry anaerobic (TheDA) digester and the mesophilic dry anaerobic (MeDA) digester were operated under the same conditions of temperature $\left(38^{\circ} \mathrm{C}\right)$. Subsequently, the TheDA digester was gradually shifted from the mesophilic condition $\left(38^{\circ} \mathrm{C}\right)$ to the thermophilic condition $\left(55^{\circ} \mathrm{C}\right)$ at a rate of $1{ }^{\circ} \mathrm{C}$ per two days until it reached $55^{\circ} \mathrm{C}$. This was done to minimize the shock due to rising temperatures during transient conditions (Nguyen et al., 2017).

In order for the digesters to operate at the designed load without shock loading, the digesters were operated in steps of transition by stepwise increasing of the SLR. After each increase of the SLR, the digesters were monitored until the results showed stable levels. Similarly, increasing the load was repeated until the digesters reached the designed load.

\subsection{Analysis}

To appraise the performance of the digesters, sludge samples (input and output) and the generated biogas were collected and analyzed daily throughout all phases of operation.

The sludge samples were characterized by measuring the concentration of TS, VS, $\mathrm{TN}, \mathrm{NH}_{4}-\mathrm{N}$, TCOD, and $\mathrm{pH}$, according to standard methods (Apha, 2005). The volume of produced biogas in each digester was measured daily with a wet gas meter (W-NK-0.5, Shinagawa Corporation, Japan). Daily produced gas samples were collected in Tedlar ${ }^{\circledR}$ bags and analyzed for composition $\left(\mathrm{CH}_{4}, \mathrm{CO}_{2}, \mathrm{NH}_{3}\right.$-gas, $\left.\mathrm{H}_{2} \mathrm{~S}\right)$ using a biogas analyzer (GSR-3100, Sensoronic, South Korea). VFAs were determined using a packed-column gas chromatograph (Agilent 7890A, Agilent Technologies, Inc., USA), equipped with a flame ionization detector and capillary gas chromatography (GC) column SGE BP21, under the operational conditions described previously 
by Nguyen et al. (2016). GC calibration was done under the guidance of the devices' manufacturers and suppliers.

\subsection{Calculations}

The daily energy yields (Eqs. (1); (2)) and specific recoverable electrical energy (Eq. (3)) were calculated as follows.

Daily energy yield $(\mathrm{kW} \mathrm{h/day)}$

$$
=10.4\left(\mathrm{~kW} \mathrm{~h} / \mathrm{m}^{3}\right) \times \text { Daily methane production }\left(\mathrm{m}^{3} / \text { day }\right)
$$

Daily energy yield $(\mathrm{MJ} /$ day $)=40\left(\mathrm{MJ} / \mathrm{m}^{3}\right)$

$\times$ Daily methane production $\left(\mathrm{m}^{3} /\right.$ day $)$

Specific recoverable electrical energy

$$
=\frac{\text { Dail energy yield }(\mathrm{kW} \mathrm{h} / \text { day })}{\text { Feeding }(\text { ton } / \text { day })}
$$

For these calculations, it was assumed that $1 \mathrm{~m}^{3}$ methane provides an energy equivalent of approximately $10.4 \mathrm{~kW} \mathrm{~h}$ (Ahern et al., 2015) or 40 megajoules (MJ) (Yin et al., 2016).

\section{Results and discussion}

\subsection{Effect of SLR on organic matter reduction}

Overall, the results indicated that the VS removal efficiency of both the TheDA and MeDA digesters after stabilization increased in direct proportion to an increase in SLR for all phases (Figs. 2(a,c) and S1(a,c)). During P1, P2, P3, and P4, the median VS removal efficiencies after stabilization by the MeDA digester were $43.98 \%$, 44.55\%, 63.37\%, and $74.02 \%$, respectively (Fig. 2(a)), and 43.98\%, 46.37\%, 59.20\%, and 80.98\% for the TheDA digester, respectively (Fig. 2(b)) The median VS removal efficiency did not differ significantly between the two digesters during P1 and P2. However, the fluctuation range of VS removal efficiency during P2 in the TheDA digester was wider than it was in the MeDA digester, which can be attributed to the differences in adaptation of the anaerobic microorganisms in the digesters.

In the TheDA digester, during the initial P3 of transition from mesophilic conditions to thermophilic conditions, by raising the temperature in the TheDA digester at the rate of $1{ }^{\circ} \mathrm{C}$ every two days. It seems the anaerobic microorganisms struggled to adapt and competed with each other (Figs. S1 and S2). Consequently, the median VS removal efficiency following stabilization of the TheDA digester (59.20\%) was a bit lower than it was in the MeDA digester (63.37\%). However, during P4, when the TheDA digester adapted to the thermophilic conditions, the VS removal efficiency of the TheDA digester (80.98\%) was significantly higher than it was in the MeDA digester (74.02\%). Montero et al. (2009) reported that the VS removal efficiency, $\mathrm{CH}_{4}$ content, and $\mathrm{CH}_{4}$ production yield of thermophilic dry $\mathrm{AD}$ of the organic fraction of municipal solid waste were $80 \%, 40.9 \%$, and $0.3 \mathrm{~m}^{3} / \mathrm{kg}$ COD removal, respectively.

Similarly, in the test case, the specific organic consumed in both digesters also tended to increase proportionally with increasing SLR (Figs. 2(b,d) and S1(b,d)). In particular, during phases P1, P2, 
$\mathrm{P} 3$, and $\mathrm{P} 4$, the median specific organics consumed were $0.95,1.60,4.55$, and $6.38 \mathrm{~kg} \mathrm{VS} / \mathrm{m}^{3}$ day, respectively, for the TheDA digester and $0.95,1.66,4.25$, and $6.98 \mathrm{~kg} \mathrm{VS} / \mathrm{m}^{3}$ day for the MeDA digester, respectively.
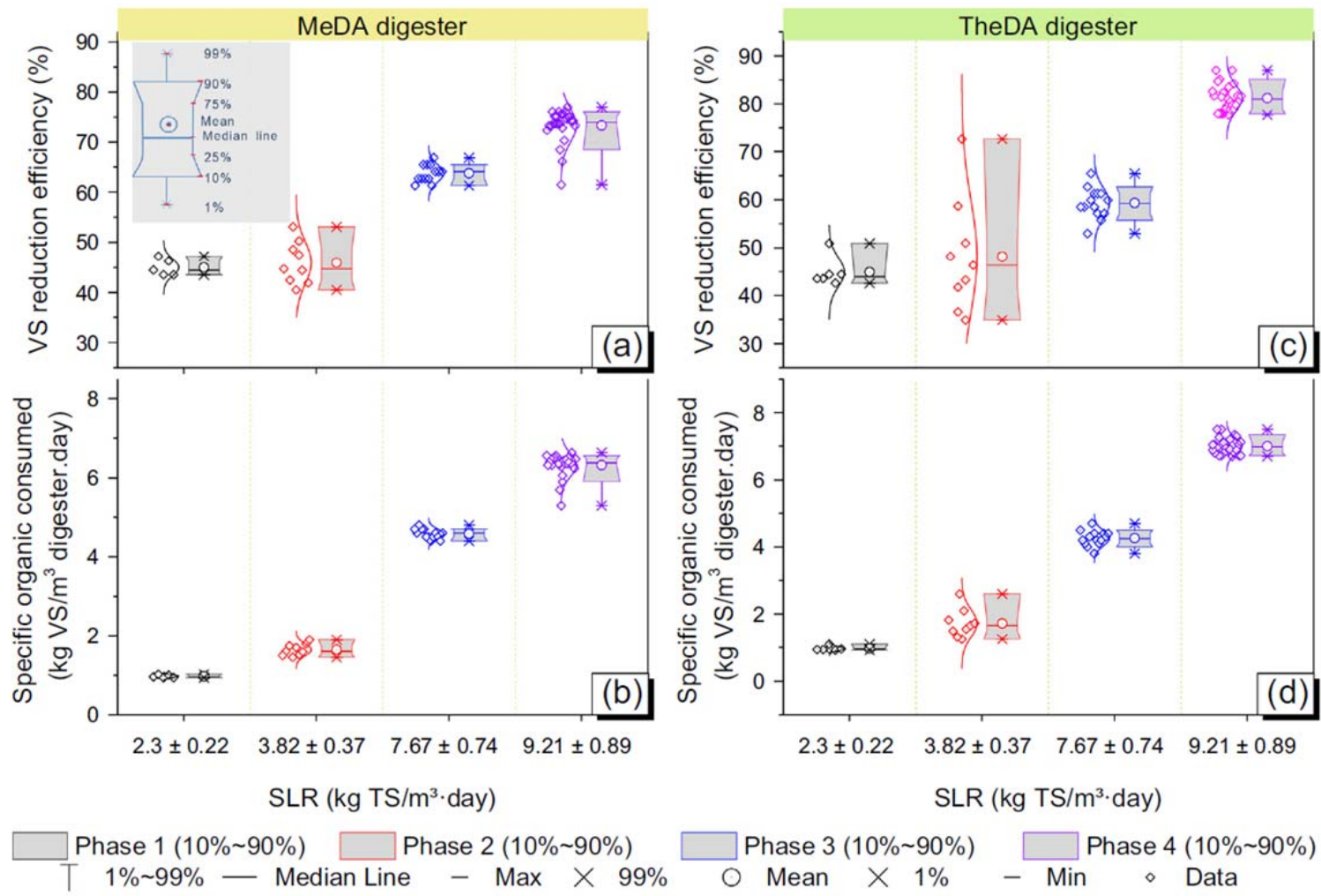

Fig. 2. Organic matter reduction in the dry digesters during stable operation under varying SLRs and either mesophilic or thermophilic conditions

Consequently, the results clearly indicate that by increasing the SLR, the efficiency in removing organic matter increased in both types of $\mathrm{AD}$. However, the conversion efficiency of organic matter in the digester operated under thermophilic conditions was approximately $10.4 \%$ greater than it was in the digester operated under mesophilic conditions. Additionally, the highest VS removal efficiency occurred during $\mathrm{P} 4$, the respective 90th (75th) VS reduction percentiles were $76.10 \%(75.17 \%)$ in the TheDA digester and $85.34 \%$ (82.54\%) in the MeDA digester. This result could be due to various groups and species of microorganisms increasingly present in quantity and activity in digesters, as abundant organic matter (SLR increasing), which they could generally acts and promotes higher conversion rates in a wide variety of soluble and particulate organic matters simultaneously, turning it into biogas and energy source. The variations in VS reduction and specific organics consumed in both digesters during the operation can be found more detail in Fig. S1.

\subsection{Effect of SLR on biogas production}

Daily biogas production, $\mathrm{CH}_{4}$ content, and specific biogas yield from treating $\mathrm{FW}$ using dry digestion under mesophilic and thermophilic conditions are shown in Fig. 3 and S2. 
The results in Fig. 3(a,d,c,f), in general, indicate that the relationships between daily biogas production or specific biogas production and SLR were similar, as both increased linearly in the digesters. The median daily biogas production in the digesters increased 2.56-fold (during P2) and 7.78-fold (during P3), compared with that during P1 (4.5 L/day). However, when the TheDA digester reached thermophilic conditions, the median daily biogas production from the two digesters differed significantly. During P4, the median daily biogas production considerably increased to $55.50 \mathrm{~L} /$ day (12.33-fold) for the MeDA digester and to $63.0 \mathrm{~L} /$ day (14-fold) for the TheDA digester, compared to only $4.5 \mathrm{~L}$ /day during P1 for both digesters. The 90th $(75$ th and 50th) percentiles of the daily biogas production for the MeDA and TheDA digesters were $58 \mathrm{~L} /$ day (57 and $55.5 \mathrm{~L} /$ day) and $66.2 \mathrm{~L} /$ day (65 and $63 \mathrm{~L} /$ day), respectively.
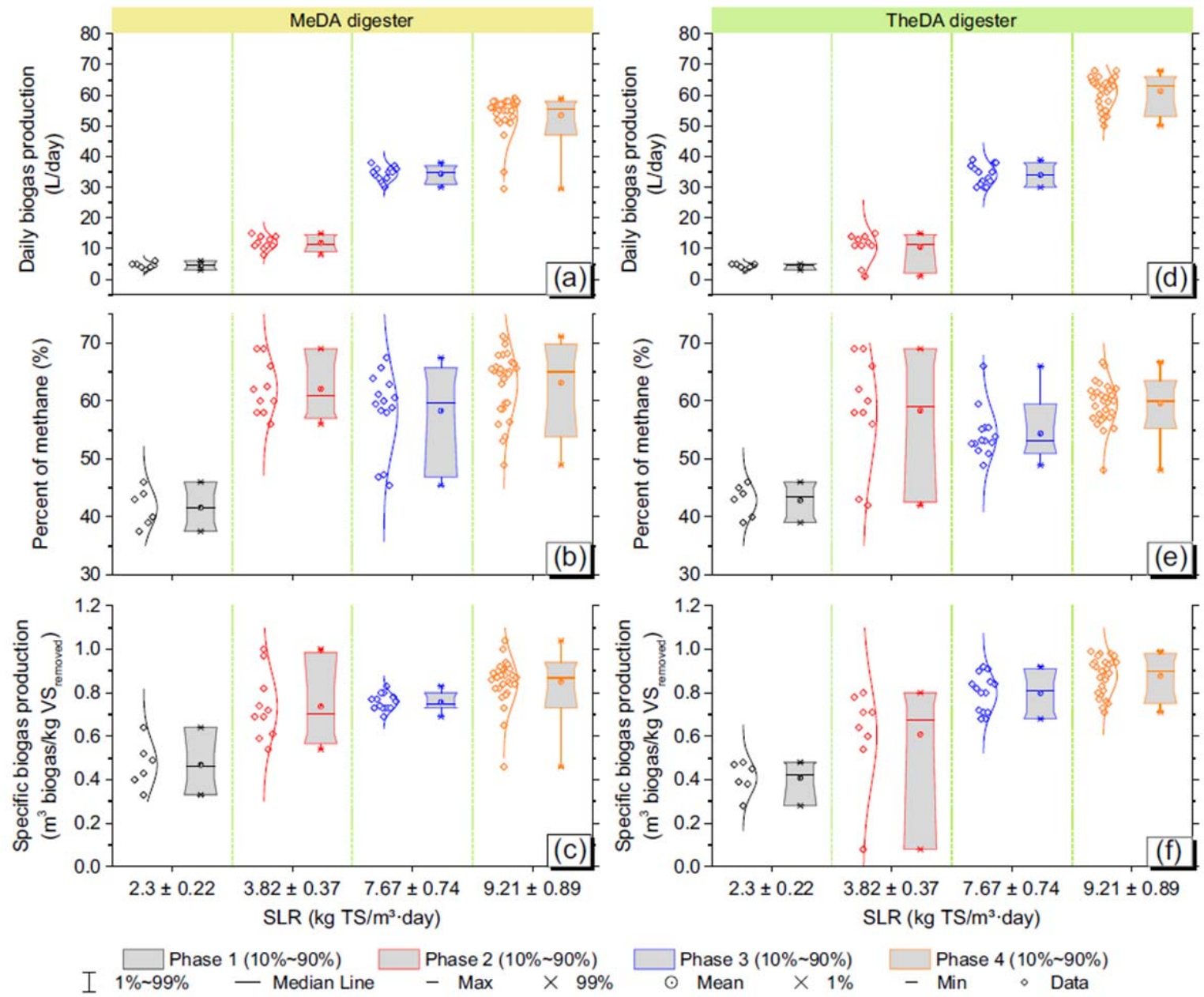

Fig. 3. Daily and specific biogas generation in the dry digesters during stable operation under various SLRs and either mesophilic or thermophilic conditions

In both digesters, the $\mathrm{CH}_{4}$ proportion of the biogas significantly increased as the SLR increased, from a median of $41.5 \%$ to $65 \%$ for the MeDA digester and from a median of $43.5 \%$ to $60.02 \%$ for the TheDA digester (Fig. 3(b,e)). Although the $\mathrm{CH}_{4}$ content of the biogas generated from the digester operated under thermophilic conditions $(60.02 \%)$ was a bit smaller than that obtained from the digester operated under mesophilic conditions $(65 \%)$, overall, the biogas production rate from the digester operated under thermophilic conditions was $0.90 \mathrm{~m}^{3}$ biogas $/ \mathrm{kg} \mathrm{VS}_{\text {removed }}$, which 
was 3.34\% higher than that obtained from the digester operated under mesophilic conditions. Therefore, the ultimate $\mathrm{CH}_{4}$ yield was higher, thus indicating the higher activity of the thermophilic anaerobic microorganisms compared to the mesophilic anaerobic microorganisms in terms of degradation and transfer into renewable energy of FW.

The observational results in this study also showed that the amount of time needed for the dry anaerobic digester to stabilize after each increase in FW loading rate was different; the higher the load, the more time the digester required to stabilize because of the adjustment needed by the anaerobic microorganisms to adapt to the respective higher loads.

The highest median specific biogas production $\left(\mathrm{CH}_{4}\right.$ content of biogas) values of $0.73 \mathrm{~m}^{3}$ biogas $/ \mathrm{kg} \mathrm{VS}$ fed and $0.9 \mathrm{~m}^{3}$ biogas $/ \mathrm{kg} \mathrm{VS}$ removed $(60.02 \%)$ for the TheDA digester and $0.65 \mathrm{~m}^{3}$ biogas $/ \mathrm{kg} \mathrm{VS}$ fed and $0.87 \mathrm{~m}^{3}$ biogas $/ \mathrm{kg} \mathrm{VS}$ removed $(65 \%)$ for the MeDA digester occurred during $\mathrm{P} 4$. The present study showed much higher renewable energy recoveries than those reported in previous studies, such as $0.23 \mathrm{~m}^{3}$ biogas $/ \mathrm{kg} \mathrm{VS}$ fed (Bolzonella et al., 2003), $0.32 \mathrm{~m}^{3}$ biogas $/ \mathrm{kg}$ $\mathrm{VS}_{\text {fed }}$ (Pavan et al., 2000), and $0.22 \mathrm{~m}^{3}$ biogas $/ \mathrm{kg} \mathrm{VS}$ fed (Cecchi et al., 1991), 80-130 $\mathrm{m}^{3}$ of biogas/ton FW (Kim and Oh, 2011), $421 \mathrm{~mL} \mathrm{CH}_{4} / \mathrm{g}$ VS (Moñino et al., 2016).

The concentrations of VFAs in each dry anaerobic digester were also monitored and analyzed during the experiments (Table S1). VFAs are intermediate products of the AD process and are possible inhibitors to the growth of anaerobic microorganisms (Pavan et al., 2000), which then leads to decreased functioning of the system. During the present study, depending on the SLR, the total concentration of VFAs varied over a wide range, from 159 to $5674 \mathrm{mg}$ TVFA/L in the MeDA digester and from 148 to $7101 \mathrm{mg}$ TVFA/L in the TheDA digester. Although the total concentration of VFAs was high in both digesters (reached 5674, and $7101 \mathrm{mg}$ TVFA/L in the MeDA digester and in the TheDA digester, respectively), VFAs had no apparent influence on the biogas production or performance of dry anaerobic digesters. This was possibly achieved as a result of the highly efficient buffering capacity offered by diverse groups and species of anaerobic microorganism in dry digesters. These findings are in contradiction with previous research (Bolzonella et al., 2003 ; Franke-Whittle et al., 2014). The superiority of the study over another could be attributed to the presence and existence of various groups and species of the resident microorganisms at great density (concentration) in the dry anaerobic digesters, with each microorganism having its own optimum level of VFAs. In addition, the analytical results indicated that acetic acid was always the major component of total VFAs during the experiments, accounting for $53.95-77.06 \%$ in the MeDA digester samples and 36.62-69.95\% in the TheDA digester samples. Furthermore, the proportion of individual VFA components occurred in the following order: acetic acid $>$ propionic acid $>$ butyric acid $>$ other VFAs, which coincided with the results documented by $\mathrm{Li}$ et al. (2015). The $\mathrm{pH}$ values were monitored, and varied within the acceptable range (6.6-8.1), in both digesters during the course of this work.

\subsection{Renewable energy self-production potential}

Global demand for energy is increasing at a time when fossil energy sources are increasingly being depleted. This has important consequences and risks to humankind and the environment. Finding and exploiting alternative sustainable energy sources are challenges to achieving sustainable social development (Hosseini et al., 2015; Yu et al., 2016). It has been widely 
accepted that FW is a biomass resource with great potential for generating renewable energy through dry AD processes, although such processes have not been fully established and exploited (Pham et al., 2015), especially in South Korea.

The influence of FW loading rate on daily energy yields and specific recoverable electrical energy during dry digestion under thermophilic and mesophilic conditions was estimated, as shown in Fig. 4. The median rate of daily energy yield and median specific recoverable electrical energy showed increasing tendencies, from 0.02 to $0.37 \mathrm{~kW} \mathrm{~h}$ /day and $0.20-0.93 \mathrm{MW} \mathrm{h} /$ ton $\mathrm{FW}$, respectively, for the MeDA digester and from 0.02 to $0.39 \mathrm{~kW} \mathrm{~h} /$ day and $0.20-0.98 \mathrm{MW} \mathrm{h} / \mathrm{ton}$ FW, respectively, for the TheDA digester, as the SLR (FW loading rate) increased from 2.3 to $9.21 \mathrm{~kg} \mathrm{TS} / \mathrm{m}^{3}$ day (Fig. 4). Furthermore, the highest median daily energy yields occurred during $\mathrm{P} 4$, with $0.37 \mathrm{~kW} \mathrm{~h} /$ day $(1.43 \mathrm{MJ} /$ day) and $0.39 \mathrm{~kW} \mathrm{~h} /$ day $(1.51 \mathrm{MJ} /$ day) for the MeDA and TheDA digesters, respectively, which were 19.06-fold and 20.12-fold higher than that obtained during P1 ( $0.02 \mathrm{~kW} \mathrm{h/day} \mathrm{or} 0.08 \mathrm{MJ} /$ day). This means that larger amounts of FW (organic matter) correspond to increased VS reduction, and renewable energy (biogas production) potential could be transformed better by dry AD under thermophilic conditions, compared to mesophilic conditions. For example, during P4, more than $14.8 \%$ extra biogas was recovered, and VS was reduced more than $10.4 \%$ under thermophilic conditions, compared with those under mesophilic conditions in the dry anaerobic digester.
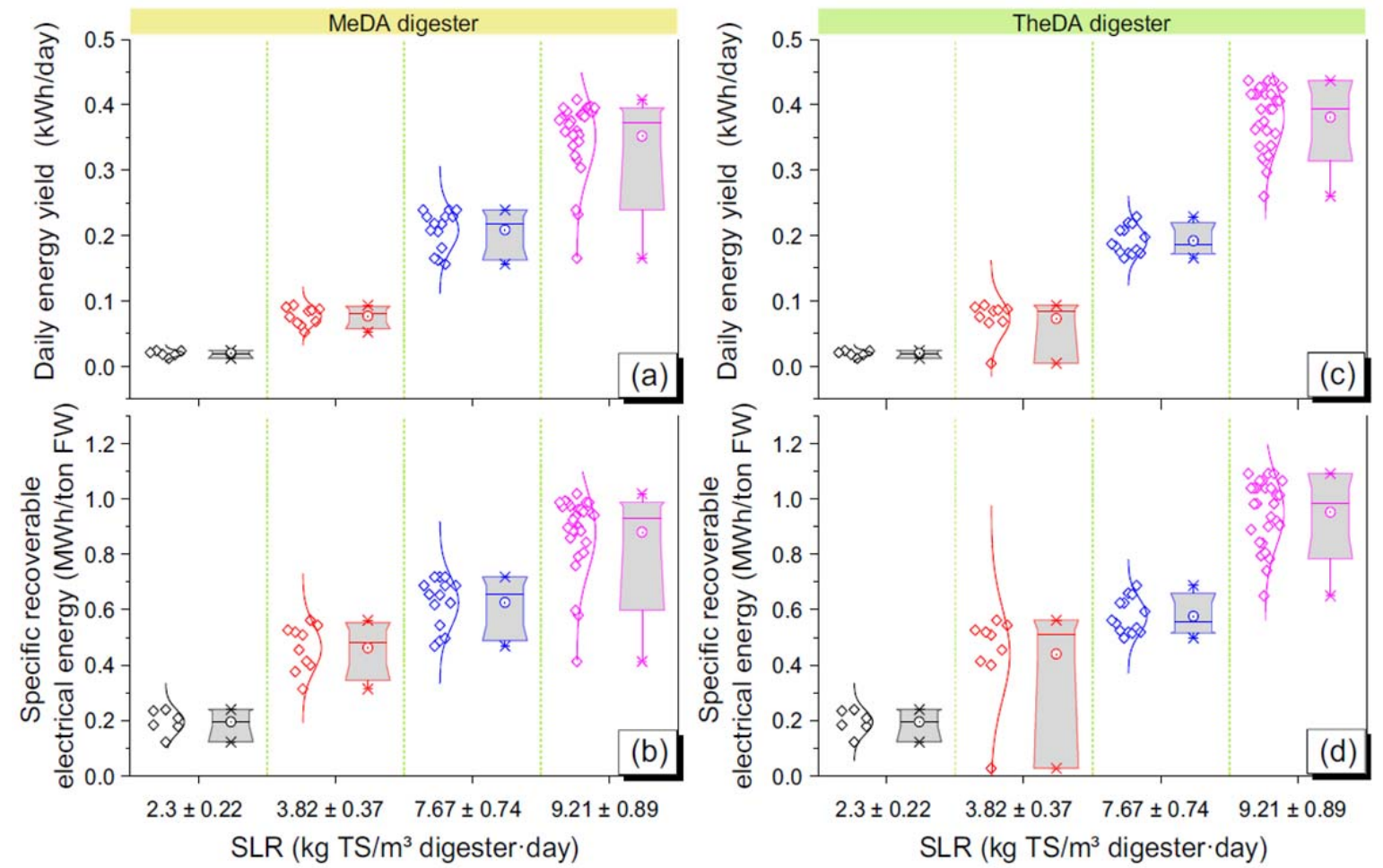

Phase 1 (10\% 90\%) $\square$ Phase 2 (10\% 90\%) Phase $3(10 \% \sim 90 \%) \quad \square$ Phase 4 (10\% 90\%) T $1 \% \sim 99 \% \quad-$ Median Line - Max $\times 99 \% \quad \odot$ Mean $\times 1 \% \quad-$ Min

Fig. 4. Daily energy yields and specific recoverable electrical energy in the dry digesters under varying SLRs and either mesophilic or thermophilic conditions 
Total electrical energy required to maintain the daily operation of the MeDA digester and TheDA digester, was determined based on the sum of electrical energy consumed versus uptime of all electrical appliances used in each system. The results indicated that throughout the study periods, the total electrical energy required to maintain the operation of the digesters varied depending on the environmental temperature, which was in the range of $0.290-0.539 \mathrm{~kW} \mathrm{~h} /$ day for MeDA digester, and $0.683-0.965 \mathrm{~kW} \mathrm{~h} /$ day for TheDA digester. In addition, the specific energy requirement $(\mathrm{MW} \mathrm{h} /$ ton of $\mathrm{FW}$ ) per tons of treated $\mathrm{FW}$ is calculated using total electrical energy required for operating digesters, divided by the amount of food waste loaded into the digesters, with quantities in the range of 2.896-5.395 MW h/ton of FW (P1), 1.81-3.372 MW h/ton of FW (P2), 0.87-1.62 MW h/ton of FW (P3), and 0.724-1.349 MW h/ton of FW (P4), for MeDA digester, and 6.826-9.647 MW h/ton of FW (P1), 4.267-6.029 MW h/ton of FW (P2), 2.052.897 MW h/ton of FW (P3), and 1.707-2.412 MW h/ton of FW (P4), for TheDA digester (Table $\mathrm{S} 2$ ). It was found that although TheDA digester was more suitable for biogas generation and VS reduction than a MeDA digester. However, in contrast, more energy was consumed in TheDA digester due to maintaining it at higher temperature. Furthermore, the specific energy requirement for FW treatment in both digesters was reduced, as the SLR increased.

Rough estimates of the total yearly electricity that could be obtained from the biogas generated by using results obtained during P4 in this study, and total annual FW generation in South Korea, are shown in Fig. 5. Between 2003 and 2014, the large volume of FW generated in South Korea, from 4.2 to 5.5 million tons/year, corresponded to a total amount of electricity production that potentially could be recovered of 3.9-5.4 million MW h/year, if FW was treated using the proposed technology under mesophilic or thermophilic conditions. For example, by 2014, the total electrical energy potential derived/recovered from FW in South Korea was estimated as 4.66 million MW h/year, which is equivalent to US\$279.53 million per year, via the MeDA digester and 4.92 million MW h/year, which is equivalent to US\$294.97 million per year, via the TheDA digester (Fig. 5). This means that higher electrical energy retrieval as well as greater economic benefits were realized from the dry AD process under thermophilic conditions, compared with the mesophilic conditions. Moreover, the results showed that recovering electrical energy from FW via these technologies has great potential and is expected to contribute significantly to clean electrical supply in South Korea.

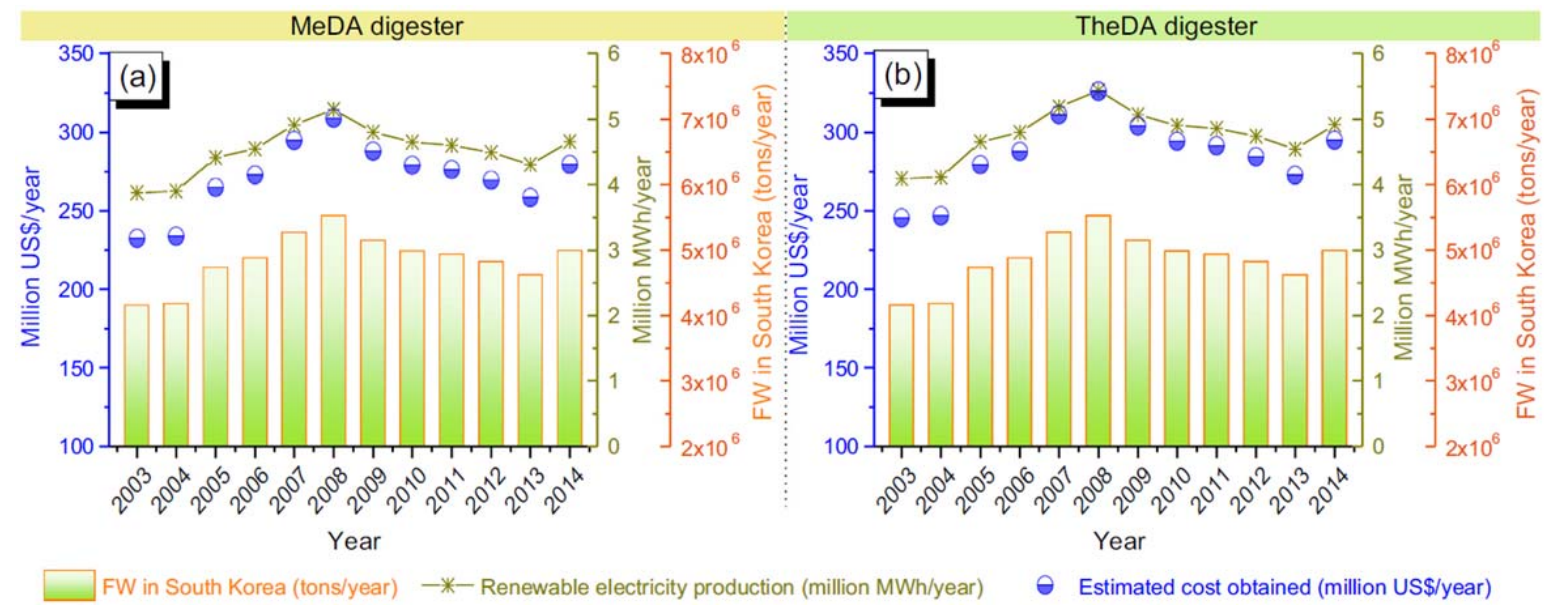

Fig. 5. Yearly FW generation in South Korea and estimates of the potential and economic value of recoverable electrical energy via the (a) MeDA digester and (b) TheDA digester 
Further evaluation revealed that the estimated electrical energy output produced from handling one ton of FW by the TheDA or MeDA digesters, at an HRT of 25 days, potentially could be enough to treat approximately 928 or $879 \mathrm{~m}^{3}$, respectively, of wastewater. According to Nguyen et al. (2014), the electrical energy demands of municipal wastewater treated by a membrane hybrid treatment system vary from 0.92 to $1.62 \mathrm{~kW} \mathrm{~h} / \mathrm{m}^{3}$ (average of $1.06 \mathrm{~kW} \mathrm{~h} / \mathrm{m}^{3}$ ). Thus, the generated renewable electrical energy from FW treated with this technology promises to be selfproduced, allowing treatment plants to be self-sufficient.

Consequently, TheDA digestion of FW can be considered an urgently needed/promised ultimate solution, especially for the simultaneous benefits of renewable energy recovery from and mass volume reduction of FW in South Korea, both now and in the near future.

\section{Conclusions}

Dry AD processes were investigated for valorization of South Korean's FW, with results demonstrating that this technological approach is effective and reliable. Raising the FW loading rate not only increased the VS reduction rate but also considerably increased renewable energy production, in both the thermophilic and mesophilic dry digesters. Both digesters were most effective during P4 (SLR: $9.21 \pm 0.89 \mathrm{~kg} \mathrm{TS} / \mathrm{m}^{3}$ day) than the other phases, when the medians of the specific biogas production rate and VS reduction were $0.73 \mathrm{~m}^{3} / \mathrm{kg} \mathrm{VS}_{\text {fed }}$ and $80.98 \%$, respectively, in the TheDA digester, which were higher than those in the MeDA digester by $14.8 \%$ and $10.4 \%$, respectively.

\section{Acknowledgements}

This work was supported by grants from the Korean Ministry of Environment, as a "Global Top Project" (Project No.: 2016002200005), and by the New \& Renewable Energy Core Technology Program of the Korea Institute of Energy Technology Evaluation and Planning (KETEP) granted financial resource from the Ministry of Trade, Industry \& Energy, Republic of Korea (Project No.: 20143030101040). The authors are grateful for the research collaboration between Kyonggi University and University of Technology Sydney, and also thank Mr. J.H. Cha for his research assistance with this project.

\section{Appendix A. Supplementary material}

Supplementary data associated with this article can be found, in the online version, at http://dx.doi.org/10.1016/j.wasman.2017.03.049.

\section{References}

Abbassi-Guendouz, A., Brockmann, D., Trably, E., Dumas, C., Delgenès, J.-P., Steyer, J.-P., Escudié, R., 2012. Total solids content drives high solid anaerobic digestion via mass transfer limitation. Biores. Technol. 111, 55-61.

Ahern, E.P., Deane, P., Persson, T., Ó Gallachóir, B., Murphy, JD., 2015. A perspective

on the potential role of renewable gas in a smart energy island system. Renewable Energy 78, $648-656$.

Apha, A., 2005. WEF, 2005. Standard Methods Examination Water Wastewater 21, 258-259. 
Banks, C.J., Chesshire, M., Heaven, S., Arnold, R., 2011. Anaerobic digestion of sourcesegregated domestic food waste: performance assessment by mass and energy balance. Biores. Technol. 102, 612-620.

Benbelkacem, H., Bollon, J., Bayard, R., Escudié, R., Buffière, P., 2015. Towards optimization of the total solid content in high-solid (dry) municipal solid waste digestion. Chem. Eng. J. 273, 261-267.

Bohutskyi, P., Ketter, B., Chow, S., Adams, K.J., Betenbaugh, M.J., Allnutt, F.C.T., Bouwer, E.J., 2015. Anaerobic digestion of lipid-extracted Auxenochlorella protothecoides biomass for methane generation and nutrient recovery. Biores. Technol. 183, 229-239.

Bolzonella, D., Innocenti, L., Pavan, P., Traverso, P., Cecchi, F., 2003. Semi-dry thermophilic anaerobic digestion of the organic fraction of municipal solid waste: focusing on the start-up phase. Biores. Technol. 86, 123-129.

Brown, D., Shi, J., Li, Y., 2012. Comparison of solid-state to liquid anaerobic digestion of lignocellulosic feedstocks for biogas production. Biores. Technol. 124, 379- 386.

Cecchi, F., Pavan, P., Mata Alvarez, J., Bassetti, A., Cozzolino, C., 1991. Anaerobic digestion of municipal solid waste: thermophilic vs. mesophilic performance at high solids. Waste Manage. Res. 9, 305-315.

Cho, S.-K., Im, W.-T., Kim, D.-H., Kim, M.-H., Shin, H.-S., Oh, S.-E., 2013. Dry

anaerobic digestion of food waste under mesophilic conditions: performance and methanogenic community analysis. Biores. Technol. 131, 210-217.

Environment, K.M.O., 2014. Volume-based Food Waste Fee System. Korea Ministry of Environment.

Fernández, J., Pérez, M., Romero, L.I., 2008. Effect of substrate concentration on dry mesophilic anaerobic digestion of organic fraction of municipal solid waste (OFMSW). Biores. Technol. 99, 6075-6080.

Fisgativa, H., Tremier, A., Dabert, P., 2016. Characterizing the variability of food waste quality: A need for efficient valorisation through anaerobic digestion. Waste Manage. 50, 264-274.

Fitamo, T., Boldrin, A., Boe, K., Angelidaki, I., Scheutz, C., 2016. Co-digestion of food and garden waste with mixed sludge from wastewater treatment in continuously stirred tank reactors. Biores. Technol. 206, 245-254.

Forster-Carneiro, T., Pérez, M., Romero, L.I., 2008. Anaerobic digestion of municipal solid wastes: Dry thermophilic performance. Biores. Technol. 99, 8180-8184.

Franke-Whittle, I.H., Walter, A., Ebner, C., Insam, H., 2014. Investigation into the effect of high concentrations of volatile fatty acids in anaerobic digestion on methanogenic communities. Waste Manage. 34, 2080-2089.

Gonzalez-Fernandez, C., Sialve, B., Molinuevo-Salces, B., 2015. Anaerobic digestion of microalgal biomass: Challenges, opportunities and research needs. Biores. Technol. 198, 896-906.

Hamilton, H.A., Peverill, M.S., Müller, D.B., Brattebø, H., 2015. Assessment of food waste prevention and recycling strategies using a multilayer systems approach. Environ. Sci. Technol. 49, 13937-13945.

Hosseini, S.E., Wahid, M.A., Ganjehkaviri, A., 2015. An overview of renewable hydrogen production from thermochemical process of oil palm solid waste in Malaysia. Energy Convers. Manage. 94, 415-429.

Huang, W., Huang, W., Yuan, T., Zhao, Z., Cai, W., Zhang, Z., Lei, Z., Feng, C., 2016. 
Volatile fatty acids (VFAs) production from swine manure through short-term dry anaerobic digestion and its separation from nitrogen and phosphorus resources in the digestate. Water Res. 90, 344-353.

Kim, D.-H., Oh, S.-E., 2011. Continuous high-solids anaerobic co-digestion of organic solid wastes under mesophilic conditions. Waste Manage. 31, 1943-1948.

Korea Ministry of Environment, W.M.R.B., 2016. Korea Ministry of Environment.

Lee, S., Paik, H.S., 2011. Korean household waste management and recycling behavior. Build. Environ. 46, 1159-1166.

Li, C., Champagne, P., Anderson, B.C., 2015. Enhanced biogas production from anaerobic codigestion of municipal wastewater treatment sludge and fat, oil and grease (FOG) by a modified two-stage thermophilic digester system with selected thermo-chemical pretreatment. Renewable Energy 83, 474-482.

Lim, S.-J., Kim, B.J., Jeong, C.-M., Choi, Jdr., Ahn, YH., Chang, HN., 2008. Anaerobic organic acid production of food waste in once-a-day feeding and drawing-off bioreactor. Biores. Technol. 99, 7866-7874.

Moñino, P., Jiménez, E., Barat, R., Aguado, D., Seco, A., Ferrer, J., 2016. Potential use of

the organic fraction of municipal solid waste in anaerobic co-digestion with wastewater in submerged anaerobic membrane technology. Waste Manage. 56, 158-165.

Montero, B., García-Morales, J.L., Sales, D., Solera, R., 2009. Analysis of methanogenic activity in a thermophilic-dry anaerobic reactor: Use of fluorescent in situ hybridization. Waste Manage. 29, 1144-1151.

Nguyen, D.D., Chang, S.W., Cha, J.H., Jeong, S.Y., Yoon, Y.S., Lee, S.J., Tran, M.C., Ngo, H.H., 2017. Dry semi-continuous anaerobic digestion of food waste in the mesophilic and thermophilic modes: New aspects of sustainable management and energy recovery in South Korea. Energy Convers. Manage. 135 (2017), 445- 452.

Nguyen, D.D., Chang, S.W., Jeong, S.Y., Jeung, J., Kim, S., Guo, W., Ngo, H.H., 2016. Dry thermophilic semi-continuous anaerobic digestion of food waste: Performance evaluation, modified Gompertz model analysis, and energy balance. Energy Convers. Manage. 128, 203-210.

Nguyen, D.D., Ngo, H.H., Kim, S.D., Yoon, Y.S., 2014. A specific pilot-scale membrane hybrid treatment system for municipal wastewater treatment. Biores. Technol. 169, 52-61.

Park, S., Lah, T.J., 2015. Analyzing the success of the volume-based waste fee system in South Korea. Waste Manage. 43, 533-538.

Pavan, P., Battistoni, P., Mata-Alvarez, J., Cecchi, F., 2000. Performance of thermophilic semidry anaerobic digestion process changing the feed biodegradability. Water Sci. Technol. 41, $75-81$.

Pham, T.P.T., Kaushik, R., Parshetti, G.K., Mahmood, R., Balasubramanian, R., 2015.

Food waste-to-energy conversion technologies: Current status and future directions. Waste Manage. 38, 399-408.

Salemdeeb, R., zu Ermgassen, E.K.H.J., Kim, M.H., Balmford, A., Al-Tabbaa, A., 2017.

Environmental and health impacts of using food waste as animal feed: a comparative analysis of food waste management options. J. Clean. Prod. 140, 871-880.

Thyberg, K.L., Tonjes, D.J., 2016. Drivers of food waste and their implications for sustainable policy development. Resour. Conserv. Recycl. 106, 110-123. 
Uçkun Kiran, E., Trzcinski, A.P., Ng, W.J., Liu, Y., 2014. Bioconversion of food waste to energy: A review. Fuel 134, 389-399.

Wang, K., Yin, J., Shen, D., Li, N., 2014a. Anaerobic digestion of food waste for volatile fatty acids (VFAs) production with different types of inoculum: Effect of $\mathrm{pH}$. Biores. Technol. $161,395-401$.

Wang, M., Sun, X., Li, P., Yin, L., Liu, D., Zhang, Y., Li, W., Zheng, G., 2014b. A novel alternate feeding mode for semi-continuous anaerobic co-digestion of food waste with chicken manure. Biores. Technol. 164, 309-314.

Yin, Y., Liu, Y.-J., Meng, S.-J., Kiran, E.U., Liu, Y., 2016. Enzymatic pretreatment of

activated sludge, food waste and their mixture for enhanced bioenergy recovery and waste volume reduction via anaerobic digestion. Appl. Energy 179, 1131- 1137.

Yu, I.K.M., Tsang, D.C.W., Yip, A.C.K., Chen, S.S., Ok, Y.S., Poon, C.S., 2016. Valorization of food waste into hydroxymethylfurfural: Dual role of metal ions in successive conversion steps. Biores. Technol. 219, 338-347.

Zhang, J., Chen, M., Sui, Q., Wang, R., Tong, J., Wei, Y., 2016. Fate of antibiotic resistance genes and its drivers during anaerobic co-digestion of food waste and sewage sludge based on microwave pretreatment. Biores. Technol. 217, 28-36. Zhang, L., Lee, Y.-W., Jahng, D., 2011. Anaerobic co-digestion of food waste and piggery wastewater: Focusing on the role of trace elements. Biores. Technol.102, 5048-5059.

Zhang, R., El-Mashad, H.M., Hartman, K., Wang, F., Liu, G., Choate, C., Gamble, P., 2007. Characterization of food waste as feedstock for anaerobic digestion. Biores. Technol. 98, 929-935. 